\title{
Costus root granules improve ulcerative colitis through regulation of TGF- $\beta$ mediation of the PI3K/AKT signaling pathway
}

\author{
XIAOHONG WANG ${ }^{1}$, DAN LI $^{1}$, YONG ZHANG $^{1}$, SHUANG WU ${ }^{2}$ and FANG TANG ${ }^{1}$ \\ ${ }^{1}$ Department of Traditional Chinese Medicine, Tianjin Medical University General Hospital, Tianjin 300052; \\ ${ }^{2}$ Tianjin Red Sun Kang Rentang Pharmaceutical Sales Co., Ltd., Tianjin 360045, P.R. China
}

Received December 22, 2016; Accepted July 20, 2017

DOI: $10.3892 /$ etm.2018.5946

\begin{abstract}
Ulcerative colitis is a chronic nonspecific inflammatory disease that occurs in the colon and rectum. Costus root is a type of traditional Chinese medicine that exhibits antibacterial properties and serves an inhibitory role in the regeneration of gut bacteria. However, the molecular mechanisms underlying Costus root-mediated improvements in ulcerative colitis remain unclear. A complex formula of Costus root granules was created and investigated in the present study for its therapeutic effects in a rat model of ulcerative colitis. Ingredient dissolution into a traditional water decoction was used as a control. The potential mechanism mediated by Costus root granules was also analyzed in colonic epithelial cells isolated from the experimental rats. The results of the present study demonstrated that Costus root granule treatment inhibited inflammation in colonic tissue. Costus root granule treatment also suppressed the apoptosis of colonic epithelial cells isolated from the rat model of ulcerative colitis. Analyses of the underlying mechanisms of these effects indicated that the administration of Costus root granules increased transforming growth factor $\beta$ expression, which activated the phosphoinositide 3-kinase/RAC- $\alpha$ serine/threonine-protein kinase signaling pathway in colonic epithelial cells. Notably, the administration of Costus root granules improved stomachache, diarrhea and hematochezia in and increased the body weight of, the ulcerative colitis rats. In conclusion, these results indicate that Costus root granules markedly ameliorate inflammation of the colonic epithelium, decrease the apoptosis of colonic epithelial cells and improve colonic function, which suggests that Costus root granules are an efficient agent for the treatment of ulcerative colitis.
\end{abstract}

Correspondence to: Professor Fang Tang, Department of Traditional Chinese Medicine, Tianjin Medical University General Hospital, 68 Anshan Road, Tianjin 300052, P.R. China

E-mail: tangfangtianjin@163.com

Key words: costus root granules, ulcerative colitis, inflammation, apoptosis, phosphoinositide 3-kinase/RAC- $\alpha$ serine/threonine-protein kinase, transforming growth factor $\beta$

\section{Introduction}

Ulcerative colitis is a chronic nonspecific inflammatory disease occurring in the colon and rectum, specifically between the colon mucosa and submucosa (1). The causes of ulcerative colitis remain unknown, but the pathogenesis of inflammatory ulcerative colitis has been demonstrated to be associated with exogenous substances, genetics and the immune response (2-4). Symptoms of ulcerative colitis include diarrhea, stomachache, hematochezia and weight loss and may lead to arthritis, iridocyclitis, liver dysfunction and skin lesions (5-7). Importantly, a systematic review and meta-analysis indicated that patients with ulcerative colitis are at a higher risk of developing colorectal cancer (8). Therefore, efficient treatments for ulcerative colitis are crucial to patients for the prevention of ulcerative colitis-induced complications.

Inflammatory responses are one of the most common symptoms that patients with ulcerative colitis have (9). A previous study indicated that inflammation and oxidative stress serve roles in the perpetuation of the inflammatory process and subsequent DNA damage associated with ulcerative colitis (10). Okayasu (11) reviewed the mechanism underlying the development of ulcerative colitis and ulcerative colitis-associated carcinoma, referring mainly to summarized data, revealing the importance of inflammation in the progression of ulcerative colitis. Another study revealed the proteomic inflammation profile of patients with ulcerative colitis, as determined by a comparative analysis of inflamed and non-inflamed colon biopsies (12). These studies suggest that inhibition of inflammatory responses contributes to clinical symptom remission in patients with ulcerative colitis.

Costus root is a type of traditional Chinese medicine that has been regarded as a multifunctional drug for the treatment of metabolic diseases $(13,14)$. A previous study demonstrated that Costus root had antinociceptive and anti-inflammatory properties in experimental animals (15). In addition, the anti-inflammatory and antipyretic properties of the rhizome of Costus root were also demonstrated in carrageenan-induced paw edema and cotton pellet-induced granuloma formation (16). Furthermore, Anyasor et al (17) studied the properties of Costus root in rat models of arthritis and the results indicated that Costus root hexane leaf fractions possessed substantial anti-inflammatory and antioxidant properties against inflammatory diseases, particularly arthritis. 
These studies suggest that Costus root may be beneficial as an anti-inflammatory agent to prevent the progression of metabolism-associated diseases.

In the present study, a complex formula of Costus root granules was produced and its therapeutic effects in a rat model of ulcerative colitis were investigated. The extract of Costus root, Ingredient dissolution into a traditional water decoction (IDTWD), was used as the control to identify the therapeutic effects of Costus root. Different analyses indicated that Costus root granules exhibited the same results as IDTWD. The molecular mechanism underlying the anti-inflammatory effect of Costus root granule on colonic epithelial cells in experimental rats was examined. It has been demonstrated that the phosphoinositide 3-kinase/RAC- $\alpha$ serine/threonine-protein kinase (PI3K/AKT) pathway is involved in the regulation and release of pro-inflammatory cytokines, including tumor necrosis factor (TNF)- $\alpha$ and serves important roles in the development and progression of ulcerative colitis (18). The findings of the present study suggest that Costus root granules significantly ameliorate inflammation and apoptosis in the colonic epithelium through regulation of transforming growth factor (TGF)- $\beta$ mediation of the PI3K/AKT signaling pathway. Furthermore, Costus root granule treatment improved stomachache, hematochezia and aided weight gain in rats with ulcerative colitis.

\section{Materials and methods}

Animal study. A total of 20 male Sprague Dawley (specific-pathogen-free) rats (6 weeks old; weighing 280-320 g) were purchased from Shanghai SLAC Experimental Animals Co., Ltd. (Shanghai, China). All rats were housed under controlled temperatures $\left(23 \pm 2^{\circ} \mathrm{C}\right)$ and humidities $(55 \pm 5 \%)$ in a $12 \mathrm{~h}$ light/dark cycle with ad libitum access to food and water. An ulcerative colitis rat model was generated by induction with 2,4,6-trinitrobenzene sulphonic acid (TNBS). TNBS (80 mg/kg) was intrarectally administered to the rat colon. TNBS-induced inflammation and alterations in colon morphology were observed, with features similar to those identified in chronic inflammatory diseases in humans. Rats were divided into three groups, which were treated with Costus root, IDTWD (cat. no. 16022921) (both 1,000 mg/kg; Tianjin Red Sun Kang Rentang Pharmaceutical Sales Co., Ltd., Tianjin, China) or the same volume of PBS by gavage once daily. The treatments continued for 30 days. Symptoms of ulcerative colitis in rats were observed on days 0 and 30 as described previously (19). The present study was performed in accordance with the recommendations in the Guide for the Care and Use of Laboratory Animals of China (20). All surgical procedures were approved by the Committee on the Ethics of Tianjin Medical University General Hospital (Tianjin, China).

Cell culture. Colonic epithelial cells were isolated from the rats with ulcerative colitis according to a previously described method (21). Colonic epithelial cells were cultured in $5 \% \mathrm{CO}_{2}$ at $37^{\circ} \mathrm{C}$ with Dulbecco's modified Eagle's medium (Sigma-Aldrich; Merck KGaA, Darmstadt, Germany) supplemented with $10 \%$ fetal bovine serum (Invitrogen; Thermo Fisher Scientific, Inc., Waltham, MA, USA), penicillin and streptomycin (100 $\mu \mathrm{g} / \mathrm{ml}$; Sigma-Aldrich; Merck KGaA).
Reverse transcription-quantitative polymerase chain reaction $(R T-q P C R)$ analysis. Total RNA was extracted from the colonic epithelial cells using the RNeasy Mini kit (Qiagen Sciences, Inc., Gaithersburg, MD, USA) according to the manufacturer's protocol. A total of $1 \mu \mathrm{g}$ total RNA was reverse transcribed into cDNA using a High-Capacity cDNA reverse transcription kit (Qiagen Sciences, Inc.), according to the manufacturer's protocol and quality was confirmed using electrophoresis. cDNA (10 ng) was subjected to qPCR using a SYBR Green Master Mix system (Bio-Rad Laboratories, Inc., Hercules, CA, USA), according to the manufacturer's protocol. The expression levels of TNF- $\alpha$ and interleukin (IL)-1 $\beta, 6$ and 10 in colonic epithelial cells were measured by RT-qPCR with $\beta$-actin as an endogenous control. All forward and reverse primers were synthesized by Invitrogen (Thermo Fisher Scientific, Inc.; Table I). Following $120 \mathrm{sec}$ incubation at $95^{\circ} \mathrm{C}$, PCR was performed under the following conditions: 45 cycle denaturation at $94^{\circ} \mathrm{C}$ for $30 \mathrm{sec}$, annealing at $56^{\circ} \mathrm{C}$ for $30 \mathrm{sec}$ and elongation at $72^{\circ} \mathrm{C}$ for $30 \mathrm{sec}$. Relative mRNA expression changes were calculated using the $2^{-\Delta \Delta \mathrm{Cq}}$ method (22). The results are expressed as a fold change compared with the control group.

Western blot analysis. Western blotting was performed as previously described (23). Cells were homogenized in lysis buffer containing a protease inhibitor to perform protein extraction (Sigma-Aldrich; Merck KGaA), after which cells were centrifuged at $6,000 \mathrm{x}$ g at $4^{\circ} \mathrm{C}$ for $10 \mathrm{~min}$. Protein concentration was measured using a BCA protein assay kit (Thermo Fisher Scientific, Inc.). Protein $(10 \mu \mathrm{g})$ was separated using $12.5 \%$ SDS-PAGE and transferred to polyvinylidene difluoride membranes (EMD Millipore, Billerica, MA, USA). Proteins were then blocked with $5 \%$ bovine serum albumin (Sigma-Aldrich; Merck KGaA) for $2 \mathrm{~h}$ at $37^{\circ} \mathrm{C}$ Monoclonal rabbit antibodies directed against apoptosis regulator $\mathrm{Bcl}-2$ (Bcl-2; cat. no. ab59348), Bcl-2-associated agonist of cell death (BAD; cat. no. ab32445), cleaved caspase-3 (cat. no. ab2302), cellular tumor antigen p53 (p53; cat. no. ab1431), AKT (cat. no. ab8805), PI3K (cat. no. ab40776), TNF- $\alpha$ (cat. no. ab6671) and IL-1 $\beta$ (cat. no. ab9722), IL-6 (cat. no. ab9324) and IL-10 (cat. no. ab33471) (all 1:200; Abcam, Cambridge, UK) were incubated with the protein samples for $1 \mathrm{~h}$ at room temperature. This was followed by incubation with horseradish peroxidase (HRP)-conjugated polyclonal anti-rabbit Immunoglobulin $\mathrm{G}$ antibodies (IgG; 1:10,000; cat. no. PI-9400; Vector Laboratories, Inc., Burlingame, CA, USA) for $1 \mathrm{~h}$ at room temperature. Immunoreactive bands were visualized by enhanced chemiluminescence (substrate ECL Select ${ }^{\mathrm{TM}}$ Ventana Benchmark automated staining system; Sigma-Aldrich; Merck KGaA). The density of bands was analyzed using Quantity One software version 4.62 (Bio-Rad Laboratories, Inc.).

Immunohistochemical staining. The colonic tissues were fixed using $10 \%$ formalin solution for $12 \mathrm{~h}$ at $4^{\circ} \mathrm{C}$. Immunohistochemical staining was performed using an avidin-biotin-peroxidase-technique on colonic tissues obtained from the rats on day 30. Paraffin embedded tissue sections 4- $\mu \mathrm{m}$-thick were prepared and epitope retrieval was performed for further analysis. The paraffin sections were incubated with 
Table I. Primer sequences used for reverse transcription-quantitative polymerase chain reaction analysis.

Primer sequence $\left(5^{\prime}-3^{\prime}\right)$

\begin{tabular}{lll}
\cline { 2 - 3 } Target gene & \multicolumn{1}{c}{ Forward } & \multicolumn{1}{c}{ Reverse } \\
\hline TNF- $\alpha$ & CTACTCCCAGGTTCTCTTCAA & GCAGAGAGGAGGTTGACTTTC \\
IL-1 $\beta$ & GCAACTGTTCCTGAACTCAACT & ATCTTTTGGGGTCCGTCAACT \\
IL-6 & TAGTCCTTCCTACCCCAATTCC & TTGGTCCTTAGCCACTCCTTC \\
IL-10 & CACAAAGCAGCCTTGCAGAA & AGAGCAGGCAGCATAGCAGT \\
\hline
\end{tabular}

TNF, tumor necrosis factor; IL, interleukin.

hydrogen peroxide $(3 \%)$ for $10-15 \mathrm{~min}$ at $37^{\circ} \mathrm{C}$ and were subsequently blocked with a regular blocking solution $(5 \%$ skim milk powder) for $10-15 \mathrm{~min}$ at $37^{\circ} \mathrm{C}$. Sections were incubated with anti-Annexin antibodies (1:2,000; cat. no. ab14196; Abcam) at $4^{\circ} \mathrm{C}$ for $12 \mathrm{~h}$ following blocking. All sections were washed three times with $\mathrm{PBS}$ at $37^{\circ} \mathrm{C}$ for $5 \mathrm{~min}$ and incubated with HRP-conjugated goat anti-rabbit IgG monoclonal antibodies (1:2000; cat. no. 1706515; Bio-Rad Laboratories, Inc.) for $1 \mathrm{~h}$ at $37^{\circ} \mathrm{C}$ and were counterstained with hematoxylin or DAPI for $1 \mathrm{~h}$ at $37^{\circ} \mathrm{C}$. Images were captured using a fluorescent microscope (Olympus BX51; Olympus Corp., Tokyo, Japan) at magnification, $\mathrm{x} 400$.

Apoptosis assays. A terminal deoxynucleotidyl transferase-mediated dUTP nick end labeling (TUNEL) assay was used to analyze the level of apoptosis of colonic epithelial cells. Colonic epithelial cells were incubated with $\mathrm{CoCl}_{2}$ for $4 \mathrm{~h}$ and then placed on glass coverslips. Subsequently, colonic epithelial cells were fixed in $4 \%$ paraformaldehyde for $1 \mathrm{~h}$ at $37^{\circ} \mathrm{C}$ and washed with $\mathrm{PBS}$ for $5 \mathrm{~min}$ at room temperature. Cells were then incubated with DAPI or TUNEL stain for $30 \mathrm{~min}$ at $37^{\circ} \mathrm{C}$ using the In Situ Cell Death Detection kit, Fluorescein (Roche Applied Science, Penzberg, Germany) according to the manufacturer's protocol. Cells were counted in $\geq 3$ randomly selected fields of view using a fluorescent microscope (Olympus BX51) and Olympus Stream Image Analysis software (version 1.0; Olympus Corp.).

PI3K and AKT activity assay. Colonic epithelial cells were homogenized and then PI3K and AKT activity was analyzed. PI3K and AKT activity was measured using the PI3K and AKT Fluorimetric Drug Discovery kit (Enzo Life Sciences, Inc., Farmingdale, NY, USA), according to the manufacturer's protocol. The fluorescent intensity was analyzed using the DTX 880 Multimode plate reader (Beckman Coulter, Inc., Brea, CA, USA).

Gene knockdown with small interfering RNA (siRNA). To silence $T G F-\beta$ gene expression, colonic epithelial cells were transfected with 100 pmol of siRNA-TGF- $\beta$ (cat. no. 1002634), using siRNA-vector (cat. no. 0000110) as the control (each Applied Biosystems; Thermo Fisher Scientific, Inc.). The transfection was achieved by using the Cell Line Nucleofector ${ }^{\circledR}$ kit L (Lonza Group, Ltd., Basel, Switzerland) according to the manufacturer's protocol. Cells were used for further analysis $72 \mathrm{~h}$ following transfection.

Statistical analysis. All data are presented as the mean \pm standard deviation of experiments performed in triplicate. Statistical analysis was completed using SPSS 19.0 statistical software (IBM Corp., Armonk, NY, USA). Statistical differences between the groups were assessed using one-way analysis of variance followed by a post hoc Dunnett's test. $\mathrm{P}<0.05$ was considered to indicate a statistically significant difference.

\section{Results}

Costus root granule treatment regulates inflammatory cytokine production in colonic epithelial cells in rats with ulcerative colitis. The mRNA expression levels of IL-1 $\beta$ and TNF- $\alpha$ were significantly downregulated by Costus root granules and IDTWD in colonic epithelial cells in the experimental groups compared with the control group (Fig. 1A; P<0.01). A marked decrease in IL-1 $\beta$ and TNF- $\alpha$ protein expression was also observed (Fig. 1B). The mRNA expression levels of IL-6 and IL-10 were significantly upregulated by Costus root granules and IDTWD in colonic epithelial cells in the experimental groups compared with the control group (Fig. $1 \mathrm{C} ; \mathrm{P}<0.01$ ). A marked increase in IL-6 and IL-10 protein expression was also observed (Fig. 1D). However, no significant differences in mRNA or protein expression were identified between the Costus root granule and IDTWD groups. These results suggest that Costus root granule treatment regulates inflammatory cytokine production in colonic epithelial cells in rats with ulcerative colitis.

Costus root granule treatment inhibits the apoptosis of colonic epithelial cells in rats with ulcerative colitis. Ulcerative colitis often leads to the apoptosis of colonic epithelial cells. Immunohistochemical analysis of colonic epithelial tissues demonstrated that Costus root granules and IDTWD decreased the level apoptosis (Fig. 2A). In the colonic epithelium of rats with ulcerative colitis, the level of apoptosis significantly decreased with Costus root granule and IDTWD treatments compared with the control group (Fig. 2B; $\mathrm{P}<0.01$ ). Western blot analysis demonstrated that Costus root granule and IDTWD administration downregulated cleaved caspase-3 and BAD in colonic epithelial cells in the experimental groups (Fig. 2C). Anti-apoptotic protein (p53 and Bcl-2) expression 
A

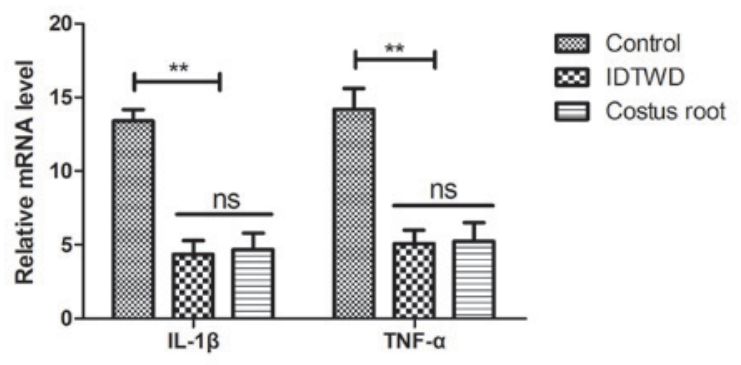

C

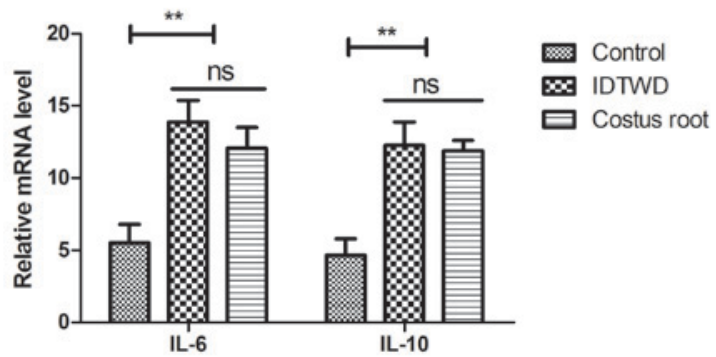

B

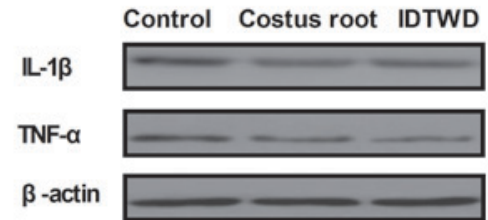

D

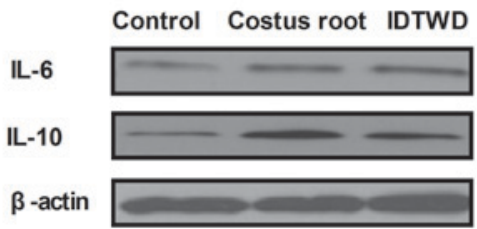

Figure 1. Costus root granule treatment reduces inflammation in colonic epithelial cells in ulcerative colitis rats. Costus root granule treatment downregulated (A) mRNA and (B) protein levels of IL-1 $\beta$ and TNF- $\alpha$ in the colonic epithelial cells of rats with ulcerative colitis compared with the control group. Costus root granules upregulated (C) mRNA and (D) protein levels of IL-6 and IL-10 in the colonic epithelial cells of rats with ulcerative colitis compared with the control group. ${ }^{* *} \mathrm{P}<0.01$. ns, not significant; IDTWD, ingredient dissolution into a traditional water decoction; IL, interleukin; TNF, tumor necrosis factor.

A
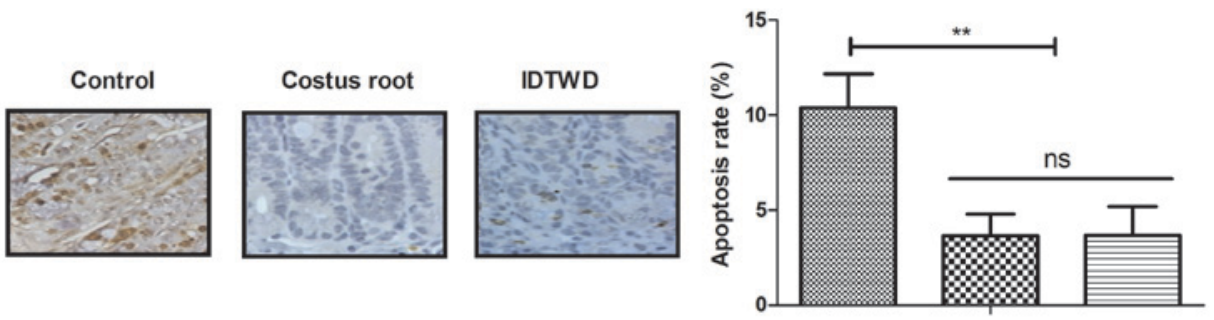

Control

$\infty$ IDTWD

Costus root

B

C
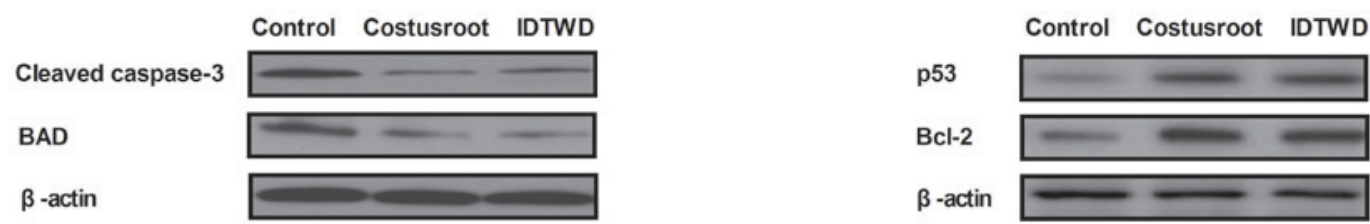

Figure 2. Costus root granule treatment inhibits the apoptosis of colonic epithelial cells from ulcerative colitis rats. (A) Immunohistochemical analyses and apoptosis assays demonstrated that Costus root granule treatment inhibited the apoptosis of colonic epithelial cells from the rat model of ulcerative colitis compared with the control group. In colonic epithelial cells from ulcerative colitis rats Costus root granule treatment (B) decreased the expression of the pro-apoptotic proteins cleaved caspase-3 and BAD and (C) upregulated the expression of the pro-apoptotic proteins p53 and Bcl-2. ${ }^{* *} \mathrm{P}<0.01$. ns, not significant; IDTWD, ingredient dissolution into a traditional water decoction; BAD, Bcl2-associated agonist of cell death; Bcl-2, apoptosis regulator Bcl-2; p53, cellular tumor antigen $\mathrm{p} 53$.

levels were upregulated by Costus root granule and IDTWD administration in colonic epithelial cells in the experimental groups (Fig. 2C). These results indicate that Costus root granule treatment inhibits the apoptosis of colonic epithelial cells in rats with ulcerative colitis.
Costus root granules improve the symptoms of ulcerative colitis in a rat model. Hematochezia results were collected from all stool samples in the $24 \mathrm{~h}$ period. The efficacy of Costus root granules was analyzed by measuring preclinical symptoms. Costus root granules and IDTWD significantly 
A

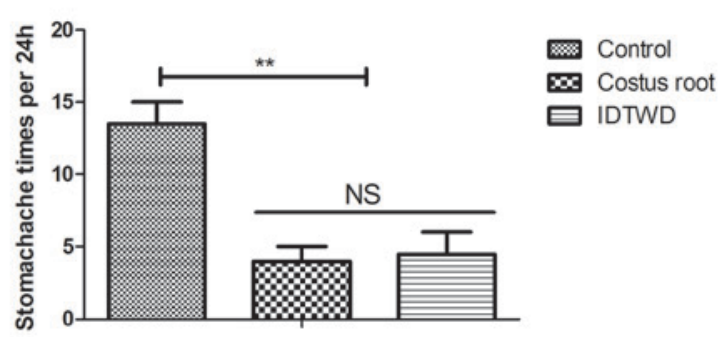

C

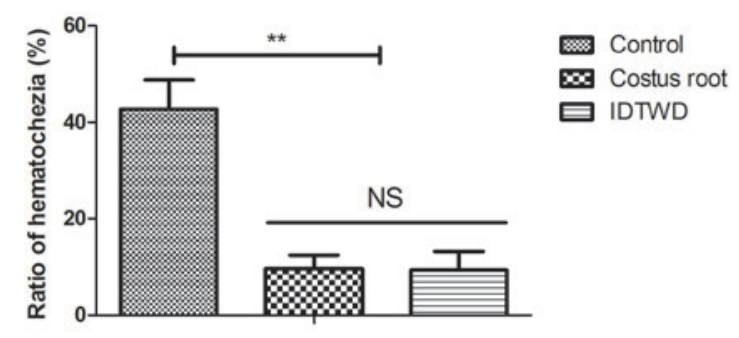

B

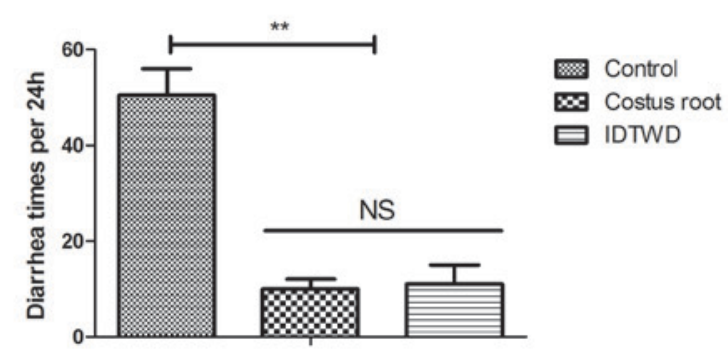

D

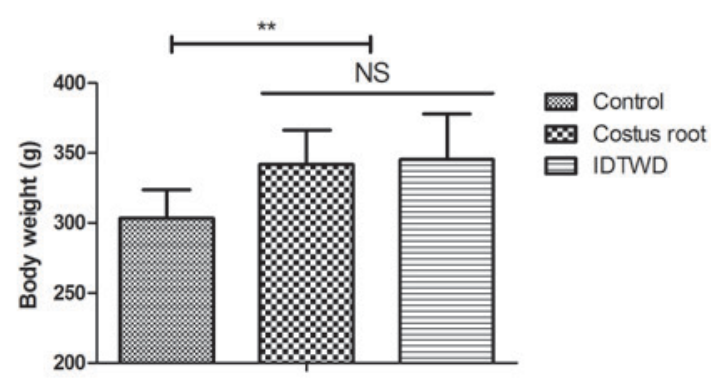

Figure 3. Costus root granule treatment improves the symptoms of ulcerative colitis in rats. Costus root granule treatment ameliorated (A) stomachache, (B) diarrhea and (C) hematochezia in rats with ulcerative colitis compared with the control group. (D) Rats treated with Costus root gained weight compared with the control group. ${ }^{* *} \mathrm{P}<0.01$. ns, not significant; IDTWD, ingredient dissolution into a traditional water decoction.

ameliorated stomachache (Fig. 3A; P<0.01), diarrhea (Fig. 3B) and hematochezia (Fig. 3C) in the experimental groups compared with the control group. Notably, Costus root granule and IDTWD treatments significantly increased the body weights of rats in the experimental groups compared with the control group (Fig. 3D; $\mathrm{P}<0.01$ ). These results suggest that Costus root granules can be beneficial in the treatment of ulcerative colitis.

Costus root granules regulate inflammation through increasing TGF- $\beta$-mediated PI3K/AKT signaling. In order to understand the potential molecular mechanism of Costus root granule-mediated improvement of ulcerative colitis, TGF- $\beta$-mediation of the PI3K/AKT signaling pathway was studied in colonic epithelial cells isolated from rats. TGF- $\beta$ expression levels increased in colonic epithelial cells following Costus root granule and IDTWD treatments compared with the control group (Fig. 4A). The activity levels of PI3K and AKT significantly increased with Costus root granule and IDTWD treatments in colonic epithelial cells compared with the control group (Fig. 4B; $\mathrm{P}<0.01$ ). Similar expression levels of the corresponding proteins were identified (Fig. 4C). In vitro assays revealed that TGF- $\beta$ knockdown significantly inhibited IDTWD (Fig. 4D; P<0.01) and Costus root granule (Fig. 4E) promoted activity of PI3K and AKT in colonic epithelial cells compared with the si-vector group.

TGF- $\beta$ knockdown also inhibited PI3K and AKT expression; however, with IDTWD (Fig. 4F) or Costus root granule (Fig. 4G) treatment PI3K and AKT expression increased. TGF- $\beta$ knockdown also increased TNF- $\alpha$ and IL-1 $\beta$ expression and decreased IL-6 and IL-10 expression, which also canceled Costus root-(Fig. 4H) and IDTWD-regulated (Fig. 4I) TNF- $\alpha$, IL-1 $\beta$ IL-6 and IL-10 expression. No marked differences in protein expression were identified between colonic epithelial cells treated with Costus root granules and the colonic epithelial cells in the control group. Taken together, these results suggest that Costus root granules regulate inflammation through regulation of TGF- $\beta$ mediation of the PI3K/AKT signaling pathway in colonic epithelial cells isolated from a rat model of ulcerative colitis.

\section{Discussion}

Ulcerative colitis is a condition that may result in toxic colonic dilatation, intestinal perforation, intestinal hemorrhage, polyps and colorectal carcinoma (24). The severity of inflammation increases the risk of ileo-anal anastomotic leak following a pouch procedure in patients with ulcerative colitis $(25,26)$. In recent years, the efficacy of traditional Chinese medicines for the treatment of digestive tract diseases has attracted global interest $(27,28)$. Costus root is a type of feverfew that exhibits therapeutic effects on gastrointestinal diseases, liver metabolic disorders and hypertension $(29,30)$. In the present study, a complex formula of Costus root granules was produced and the therapeutic efficacy of the formula was tested on a rat model of ulcerative colitis. The findings suggest that the Costus root granule formula exhibits the same anti-inflammatory and antiapoptotic efficacies as IDTWD in colonic epithelial cells isolated from rats with ulcerative colitis.

Inflammation serves an important role in the progression of ulcerative colitis $(31,32)$. Cuković-Cavka et al (33) investigated the role of anti-TNF therapy in the treatment of 
A

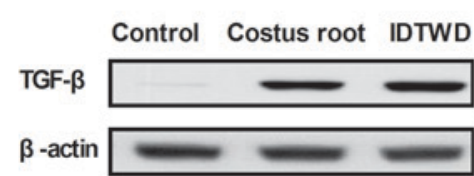

D

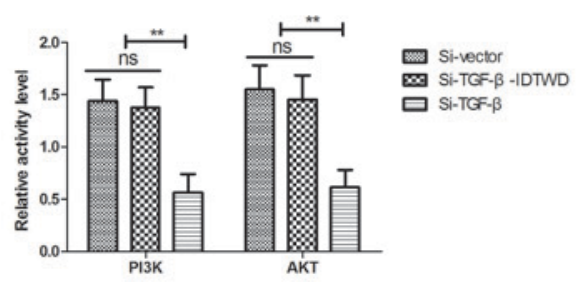

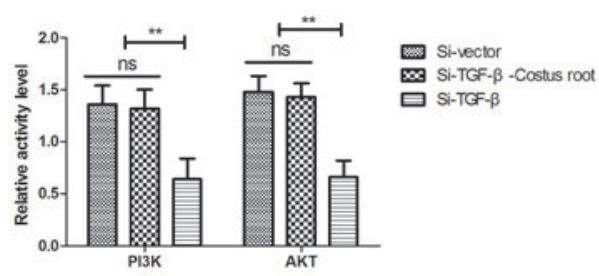

G

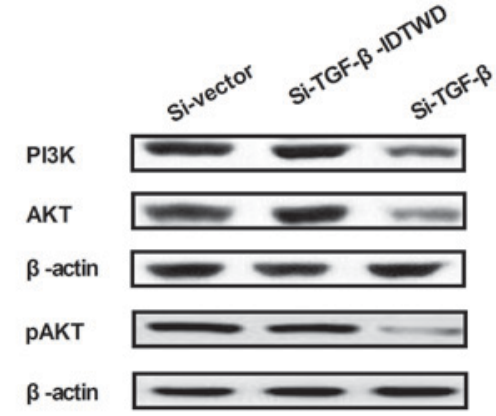

I

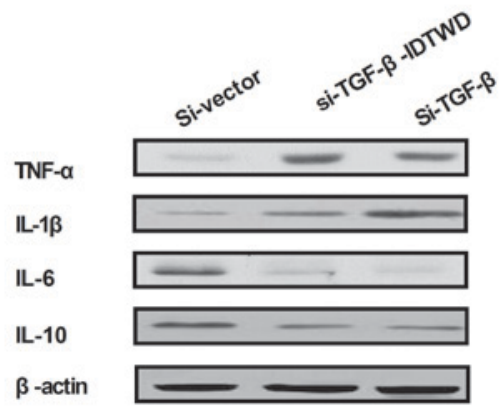

Figure 4. Costus root granule treatment regulates inflammation through increasing TGF- $\beta$-mediated PI3K/AKT signaling. (A) Costus root granule treatment increased TGF- $\beta$ expression in colonic epithelial cells compared with the control group. The (B) activity and (C) expression of PI3K and AKT increased with Costus root granule treatment in colonic epithelial cells compared with the control group. TGF- $\beta$ knockdown decreased PI3K and AKT activity in colonic epithelial cells compared with cells treated with si-TGF- $\beta$ and (D) Costus root granules or (E) IDTWD. TGF- $\beta$ knockdown inhibited the expression of PI3K and AKT in colonic epithelial cells treated with si-TGF- $\beta$ and (F) IDTWD or (G) Costus root granules. TGF- $\beta$ knockdown inhibited the expression of TNF- $\alpha$ and IL-1 $\beta, 6$ and 10 in colonic epithelial cells treated with si-TGF- $\beta$ and Costus root $(\mathrm{H})$ and IDTWD (I). ** P<0.01. ns, not significant; IDTWD, ingredient dissolution into a traditional water decoction; TGF, transforming growth factor; PI3K, phosphoinositide 3-kinase; AKT, RAC- $\alpha$ serine/threonine-protein kinase, pAKT, phosphorylated AKT; si, small interfering.

ulcerative colitis and the outcomes indicated that adequate long-term maintenance therapy with anti-TNF drugs is beneficial to patients with ulcerative colitis. IL-1 $\beta$ gene polymorphisms are associated with genetic susceptibility and steroid dependence in patients with ulcerative colitis (34). IL-10 has been identified to be differentially expressed in the small intestine and chronically inflamed colon of young pigs with dextran sodium sulfate-induced ulcerative colitis (35).
Bernardo et al (36) demonstrated that IL-6 promoted immune responses in inflamed areas in patients with ulcerative colitis, which lead to the induction of a skin-homing phenotype in dendritic and T cells. In the present study, Costus root granules downregulated TNF- $\alpha$ and IL-1 $\beta$ expression and upregulated IL-6 and IL-10 expression, in colonic epithelial cells isolated from the rat model of ulcerative colitis, indicating an inhibition of apoptosis. 
The apoptosis of colonic epithelial cells has been observed in patients with ulcerative colitis (37). The present study observed that Costus root granule treatment suppressed the apoptosis of colonic epithelial cells by upregulating p53 and Bcl-2 expression. A previous study also revealed that expression of the TGF- $\beta /$ mothers against decapentaplegic homolog (SMAD) signaling pathway was downregulated in patients with ulcerative colitis; this was analyzed by pathological and quantitative analyses of TGF- $\beta / \mathrm{SMAD}$ by immunohistochemistry (38). Additionally, the PI3K/AKT signaling pathway has been reported to be involved in the pathogenesis of ulcerative colitis (18). The results of the present study demonstrated that Costus root granules could inhibit inflammation through TGF- $\beta$-mediation of the PI3K/AKT signaling pathway in colonic epithelial cells.

In conclusion, the findings of the present study indicate that Costus root granules inhibit inflammation and the apoptosis of colonic epithelial cells and improve the symptoms of ulcerative colitis in rats. Importantly, analyses of potential mechanisms demonstrated that Costus root granules may inhibit inflammation through regulated of TGF- $\beta$ mediation of the PI3K/AKT signaling pathway in colonic epithelial cells, which may lead to improvements in stomachache, diarrhea, hematochezia and weight gain. These results suggest that Costus root granules are an efficient treatment for patients with ulcerative colitis.

\section{Acknowledgements}

The present study was supported by the Tianjin Science and Technology Correspondent Project (grant no. 16JCTPJC50000).

\section{Competing interests}

The authors declare thay they have no competing interests.

\section{References}

1. Aung PP, Bowker B, Masterpol KS and Mahalingam M: Disseminated noninterstitial granulomatous dermatitis as a cutaneous manifestation of the preleukemic state in a patient with myelodysplasia and ulcerative colitis-apropos a case and review of the literature. Am J Dermatopathol 36: e117-e120, 2014.

2. Mosli MH, Feagan BG, Sandborn WJ, D'haens G, Behling C, Kaplan K, Driman DK, Shackelton LM, Baker KA, Macdonald JK, et al: Histologic evaluation of ulcerative colitis: A systematic review of disease activity indices. Inflamm Bowel Dis 20: 564-575, 2014.

3. Morelli L, Palmeri M, Tartaglia D, Guadagni S, Di Candio G and Mosca F: Adenocarcinoma on j-pouch after proctocolectomy for ulcerative colitis-case report and review of literature. Int J Colorectal Dis 29: 1171-1173, 2014.

4. Mennigen R, Sewald W, Senninger N and Rijcken E: Morbidity of loop ileostomy closure after restorative proctocolectomy for ulcerative colitis and familial adenomatous polyposis: A systematic review. J Gastrointest Surg 18: 2192-2200, 2014.

5. Park HB, Park HC, Chung CY, Kim JS, Myung DS, Cho SB, Lee WS and Joo YE: Coexistence of solitary rectal ulcer syndrome and ulcerative colitis: A case report and literature review. Intest Res 12: 70-73, 2014.

6. Papaconstantinou I, Stefanopoulos A, Papailia A, Zeglinas C, Georgopoulos I and Michopoulos S: Isotretinoin and ulcerative colitis: A case report and review of the literature. World J Gastrointest Surg 6: 142-145, 2014.

7. Negoro A, Takano T, Tajiri H, Nezu R, Kawamura N and Brooks S: A role of colectomy in immune thrombocytopenic purpura associated with ulcerative colitis: A case report and a review of the literature. Int J Colorectal Dis 29: 1179-1180, 2014
8. Castaño-Milla C, Chaparro M and Gisbert JP: Systematic review with meta-analysis: The declining risk of colorectal cancer in ulcerative colitis. Aliment Pharmacol Ther 39: 645-659, 2014.

9. Önal İK, Beyazit Y, Şener B, Savuk B, Özer Etık D, Sayilir A, Öztaş E, Torun S, Özderın Özın Y, Tunç Demırel B, et al: The value of fecal calprotectin as a marker of intestinal inflammation in patients with ulcerative colitis. Turk J Gastroenterol 23: 509-514, 2012.

10. Jena $G$ and Trivedi PP: A review of the use of melatonin in ulcerative colitis: Experimental evidence and new approaches. Inflamm Bowel Dis 20: 553-563, 2014.

11. Okayasu I: Development of ulcerative colitis and its associated colorectal neoplasia as a model of the organ-specific chronic inflammation-carcinoma sequence. Pathol Int 62: 368-380, 2012

12. Poulsen NA, Andersen V, Møller JC, Møller HS, Jessen F, Purup S and Larsen LB: Comparative analysis of inflamed and non-inflamed colon biopsies reveals strong proteomic inflammation profile in patients with ulcerative colitis. BMC Gastroenterol 12: 76, 2012.

13. Shilpa K, Sangeetha KN, Muthusamy VS, Sujatha S and Lakshmi BS: Probing key targets in insulin signaling and adipogenesis using a methanolic extract of Costus pictus and its bioactive molecule, methyl tetracosanoate. Biotechnol Lett 31: 1837-1841, 2009.

14. Gireesh G, Thomas SK, Joseph B and Paulose CS: Antihyperglycemic and insulin secretory activity of Costus pictus leaf extract in streptozotocin induced diabetic rats and in in vitro pancreatic islet culture. J Ethnopharmacol 123: 470-474, 2009.

15. Quintans Júnior LJ, Santana MT, Melo MS, de Sousa DP, Santos IS, Siqueira RS, Lima TC, Silveira GO, Antoniolli AR, Ribeiro LA and Santos MR: Antinociceptive and anti-inflammatory effects of Costus spicatus in experimental animals. Pharm Biol 48: 1097-1102, 2010

16. Binny K, Kumar SG and Dennis T: Anti-inflammatory and antipyretic properties of the rhizome of costus speciosus (koen.) sm. J Basic Clin Pharm 1: 177-181, 2010.

17. Anyasor GN, Onajobi F, Osilesi O, Adebawo O and Oboutor EM: Anti-inflammatory and antioxidant activities of Costus afer Ker Gawl. Hexane leaf fraction in arthritic rat models. J Ethnopharmacol 155: 543-551, 2014.

18. Huang XL, Xu J, Zhang XH, Qiu BY, Peng L, Zhang M and Gan HT: PI3K/Akt signaling pathway is involved in the pathogenesis of ulcerative colitis. Inflamm Res 60: 727-734, 2011.

19. Mao JW, Tang HY, Tan XY and Wang YD: Effect of Etiasa on the expression of matrix metalloproteinase-2 and tumor necrosis factor-alpha in a rat model of ulcerative colitis. Mol Med Rep 6: 996-1000, 2012.

20. Davey G and Wu Z: Attitudes in China toward the use of animals in laboratory research. Altern Lab Anim 35: 313-316, 2007.

21. Pedersen G, Saermark T, Giese B, Hansen A, Drag B and Brynskov J: A simple method to establish short-term cultures of normal human colonic epithelial cells from endoscopic biopsy specimens. Comparison of isolation methods, assessment of viability and metabolic activity. Scand J Gastroenterol 35: 772-780, 2000.

22. Livak KJ and Schmittgen TD: Analysis of relative gene expression data using real-time quantitative PCR and the 2(-Delta Delta C(T)) method. Methods 25: 402-408, 2001.

23. Almeida Mde A, Pizzini CV, Damasceno LS, Muniz Mde M, Almeida-Paes R, Peralta RH, Peralta JM, Oliveira Rde V, Vizzoni AG, de Andrade CL, et al: Validation of western blot for Histoplasma capsulatum antibody detection assay. BMC Infect Dis 16: 87, 2016 .

24. Christophorou D, Funakoshi N, Duny Y, Valats JC, Bismuth M, Pineton De Chambrun G, Daures JP and Blanc P: Systematic review with meta-analysis: Infliximab and immunosuppressant therapy vs. infliximab alone for active ulcerative colitis. Aliment Pharmacol Ther 41: 603-612, 2015.

25. Franco AI, Escobar L, Garcia XA, Van Domselaar M, Achecar LM, Luján DR and García MJ: Mesalazine-induced eosinophilic pneumonia in a patient with ulcerative colitis disease: A case report and literature review. Int J Colorectal Dis 31: 927-929, 2016

26. Alobaid A, Torlakovic E and Kongkham P: Primary central nervous system immunomodulatory therapy-induced lymphoproliferative disorder in a patient with ulcerative colitis: A case report and review of the literature. World Neurosurg 84: 2074. e15-e19, 2015. 
27. Takayama S and Iwasaki K: Systematic review of traditional Chinese medicine for geriatrics. Geriatr Gerontol Int 17: 679-688, 2017.

28. Sun GD, Li CY, Cui WP, Guo QY, Dong CQ, Zou HB, Liu SJ, Dong WP and Miao LN: Review of herbal traditional chinese medicine for the treatment of diabetic nephropathy. J Diabetes Res 2016: 5749857, 2016.

29. Fan H, Liu F, Bligh SW, Shi S and Wang S: Structure of a homofructosan from Saussurea costus and anti-complementary activity of its sulfated derivatives. Carbohydr Polym 105: 152-160, 2014

30. Hegde PK, Rao HA and Rao PN: A review on insulin plant (Costus igneus Nak). Pharmacogn Rev 8: 67-72, 2014

31. Patil DT, Moss AC and Odze RD: Role of histologic inflammation in the natural history of ulcerative colitis. Gastrointest Endosc Clin N Am 26: 629-640, 2016.

32. Magnusson MK, Brynjólfsson SF, Dige A, Uronen-Hansson $H$, Börjesson LG, Bengtsson JL, Gudjonsson S, Öhman L, Agnholt J, Sjövall H, et al: Macrophage and dendritic cell subsets in IBD: $\mathrm{ALDH}+$ cells are reduced in colon tissue of patients with ulcerative colitis regardless of inflammation. Mucosal Immunol 9: 171-182, 2016.

33. Cuković-Cavka S, Vucelić B, Urek MC, Brinar M and Turk N: The role of anti-TNF therapy in ulcerative colitis. Acta Med Croatica 67: 171-177, 2013 (In Croatian).
34. Yamamoto-Furusho JK, Santiago-Hernández JJ, Pérez-Hernández N, Ramirez-Fuentes S, Fragoso JM and Vargas-Alarcón G: Interleukin $1 \beta$ (IL-1B) and IL-1 antagonist receptor (IL-1RN) gene polymorphisms are associated with the genetic susceptibility and steroid dependence in patients with ulcerative colitis. J Clin Gastroenterol 45: 531-535, 2011.

35. Lackeyram D, Young D, Kim CJ, Yang C, Archbold TL, Mine Y and Fan MZ: Interleukin-10 is differentially expressed in the small intestine and the colon experiencing chronic inflammation and ulcerative colitis induced by dextran sodium sulfate in young pigs. Physiol Res 66: 147-162, 2017.

36. Bernardo D, Vallejo-Diez S, Mann ER, Al-Hassi HO, Martínez-Abad B, Montalvillo E, Tee CT, Murugananthan AU, Núñez H, Peake ST, et al: IL-6 promotes immune responses in human ulcerative colitis and induces a skin-homing phenotype in the dendritic cells and Tcells they stimulate. Eur J Immunol 42: 1337-1353, 2012.

37. Seidelin JB and Nielsen $\mathrm{OH}$ : Attenuated apoptosis response to Fas-ligand in active ulcerative colitis. Inflamm Bowel Dis 14: 1623-1629, 2008

38. Xu X, Xu C, Saud SM, Lu X, Liu L, Fang L, Zhang X, Hu J and $\mathrm{Li} \mathrm{W}$ : Effect of kuijie granule on the expression of TGF- $\beta /$ Smads signaling pathway in patients with ulcerative colitis. Evid Based Complement Alternat Med 2016: 2601830, 2016. 